\title{
Thermal and photo-stability of the antioxidant potential of Spirulina platensis powder
}

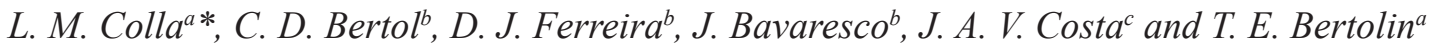 \\ ${ }^{a}$ Curso de Engenharia de Alimentos, Laboratório de Fermentações, Universidade de Passo Fundo - UPF, Campus I, \\ BR 285, CEP 99001-970, Passo Fundo, RS, Brazil \\ ${ }^{\text {bC }}$ urso de Farmácia, Instituto de Ciências Biológicas, Universidade de Passo Fundo - UPF, Campus I, BR 285, \\ CEP 99001-970, Passo Fundo, RS, Brazil
}

'Programa de Pós-graduação em Engenharia e Ciência de Alimentos, Universidade Federal do Rio Grande - FURG, Rua Engenheiro Alfredo Huch, 475, CP 474, CEP 96201-900, Rio Grande, RS, Brazil

*e-mail:1mcolla@upf.br

Received: September 13, 2015 - Accepted: February 10, 2016 - Distributed: May 31, 2017

\begin{abstract}
This work aimed to evaluate the thermal and photo stability of the antioxidant potential (AP) of the Spirulina platensis biomass. Thermal stability was established at $25^{\circ} \mathrm{C}, 40^{\circ} \mathrm{C}$ and $50^{\circ} \mathrm{C}$ for 60 days, in the dark, protected from light. Photo stability was evaluated using UV $(15 \mathrm{~W}, \lambda=265 \mathrm{~nm})$ and fluorescent $(20 \mathrm{~W}, 0.16 \mathrm{~A}$, power factor FP $>0.5$, $50 / 60 \mathrm{~Hz}, 60 \mathrm{~lm} / \mathrm{w}, 1200 \mathrm{~lm}$ ) light for 90 days in capsules, glass and Petri dishes, at room temperature. The AP of the biomass in these conditions was determined at intervals (every 7 and 30 days in the studies of thermal and photo stability, respectively) using the induction of the oxidation of a lipid system by heat and aeration. In this lipid system, the biomass submitted to degradation was used as an antioxidant. The kinetics of the reaction was determined by the Arrhenius method. Thermal degradation was found to follow zero order kinetics, whereas photo degradation followed first order kinetics. The AP decreased $50 \%$ after 50 days at $25^{\circ} \mathrm{C}$. At $40^{\circ} \mathrm{C}$ and $50^{\circ} \mathrm{C}$, the AP decreased more than $50 \%$ after 35 and 21 days of exposition, respectively. The decrease of the AP of Spirulina was more sensible to UV and fluorescence light. After 30 days of exposition, the AP decreased more than $50 \%$ in all storage conditions tested. The antioxidant potential of Spirulina platensis is easily degraded when the biomass is exposed to heat and light, indicating the need for care to be taken in its storage.
\end{abstract}

Keywords: Arrhenius, stability, kinetic, degradation, cyanobacteria, microalgal biomass.

\section{Estabilidade térmica e fotoestabilidade do potencial antioxidante de Spirulina platensis em pó}

\section{Resumo}

Este trabalho objetivou avaliar a estabilidade térmica e a foto-estabilidade do potencial antioxidante (PA) da biomassa da Spirulina platensis. A estabilidade térmica foi avaliada a $25^{\circ} \mathrm{C}, 40^{\circ} \mathrm{C}$ e $50^{\circ} \mathrm{C}$ por 60 dias. A foto-estabilidade foi avaliada usando luz UV ( $15 \mathrm{~W}, \lambda=265 \mathrm{~nm})$ e fluorescente $(20 \mathrm{~W}, 0.16 \mathrm{~A}$, fator de potência $\mathrm{FP}>0.5,50 / 60 \mathrm{~Hz}, 60 \mathrm{~lm} / \mathrm{w}$, $1200 \mathrm{~lm}$ ) por 90 dias em cápsulas, vidro e placas de Petri. O PA da biomassa nessas condições foi determinado em intervalos de tempo (a cada 7 e 30 dias nos estudos de estabilidade térmica e foto-estabilidade, respectivamente), usando a indução da oxidação de um sistema lipídico por calor e aeração. Neste sistema lipídico, a biomassa submetida à degradação foi usada como antioxidante. A cinética da reação foi determinada pelo método de Arrhenius. A degradação térmica seguiu uma cinética de zero ordem, enquanto que a fotodegradação seguiu uma cinética de primeira ordem. O PA diminuiu $50 \%$ depois de 50 dias a $25^{\circ} \mathrm{C}$. A $40^{\circ} \mathrm{C}$ e $50^{\circ} \mathrm{C}$, o PA diminuiu mais de $50 \%$ depois de 35 e 21 dias de exposição, respectivamente. A diminuição do PA da Spirulina foi mais sensível à luz UV e fluorescente. Depois de 30 dias de exposição, o PA diminuiu mais de 50\% em todas as condições de armazenamento testadas. O potencial antioxidante da Spirulina platensis é facilmente diminuído quando a biomassa é exposta ao calor e a luz, indicando a necessidade de cuidados durante seu armazenamento.

Palavras-chave: Arrhenius, estabilidade, cinética, degradação, cianobactéria, biomassa microalgal. 


\section{Introduction}

Spirulina platensis is a filamentous photoautotrophic cyanobacterium that inhabits various environments, such as soils and marshes, alkaline lakes, brackish, marine and candy water, forming a green scum on the water surface (Richmond, 1990; Vonshak, 1997). The microalgae present an interesting nutritional potential (Henrikson, 1995) as they are marketed mainly in pharmacies as a dietary supplement. Spirulina is legally authorized as a food supplement in Europe, Japan, the United States of America and Brazil, with no toxic effects (Belay et al., 1993; Von Der Weid et al., 2000; Brasil, 2013).

Several studies have reported the use of microalgae in the treatment and prevention of various diseases, such as hyperlipidemia (Colla et al., 2008; Bertolin et al., 2009), obesity (Becker et al., 1986), compromised immune system (Pérez et al., 2002), diabetes (Moura et al., 2012), protein deficiency (Donato et al., 2010), hypertension (Torres-Duran et al., 2007) and others (Ambrosi et al., 2008). The nutraceutical properties of these microalgae have been attributed to their chemical composition, which is rich in proteins (60-70\%) (Henrikson, 1995), polyunsaturated fatty acids (Colla et al., 2004), phenolic compounds (Colla et al., 2007) and phycocyanin (Silva, 2008). Other properties, such as the antimicrobial action (Parisi et al., 2009; Kaushik and Chauhan, 2008; Mala et al., 2009; Kumar et al., 2011; Sarada et al., 2011; Souza et al., 2011; El-Sheekh et al., 2014) and its influence on the survival of lactic acid bacteria (Perez et al., 2007), have been reported. Among the properties of microalgae, the antioxidant action by phenolic compounds and phycocyanin has been extensively studied in vitro (Jaime et al., 2005; Souza et al., 2006; Shalaby and Shanab, 2013) and in vivo systems (Guarienti et al., 2010; Bertolin et al., 2011).

Evidence of photo stability and thermo stability of different substances and organic products become increasingly important as the need for the food industry to develop food with health order. Studies aimed at understanding these functional activities, especially with regard to antioxidants, are justified because of the growing appeal of the importance of food in health and longevity of man (Benites et al., 2015; Bittencourt-Oliveira et al., 2015; Formagio et al., 2015).

The microalgae biomass available for sale in pharmacies has been used primarily as a dietary supplement; however, to extend the use of these bio-compounds as nutraceuticals due to their antioxidant potential, knowledge about the care necessary for the maintenance of this potential is necessary. Chemical reactions, such as hydrolysis and oxidation, may occur due to environmental factors (temperature, humidity, light, atmospheric gases, $\mathrm{pH}$ and microbial contamination), potentially directly interfering with the stability of a compound (Brasil, 2005). During the degradation, the increased temperature could provide the activation energy required to break the chemical bonds (Carstensen and Rhodes, 2000).
In this context, this work aimed to evaluate the antioxidant potential of Spirulina platensis powder upon exposure to different conditions of temperature and light. These results can contribute to determine the best storage conditions, especially by pharmacies that sell the microalgae as capsules.

\section{Material and Methods}

\subsection{Microalgae Spirulina platensis}

The powder of Spirulina platensis was provided by the Laboratory of Biochemical Engineering of Federal University of Rio Grande, Brazil (FURG). This biomass was produced in a pilot plant unit in the city of Santa Vitória do Palmar, state of Rio Grande do Sul, Brazil. After cultivation, the biomass was collected and dried at $50^{\circ} \mathrm{C}$, being maintained at $-20^{\circ} \mathrm{C}$ until be tested and sieved (the perforations on the sieve being $150 \mathrm{mesh}$ ). The biomass cultivated in these conditions can present, depending of the time of collection, 50 to $60 \%$ of carbohydrates, 30 to $40 \%$ of proteins and about $5 \%$ of lipids, according to recent experiments accomplished by our group.

\subsection{Experimental design}

For studies of thermal stability, $5 \mathrm{~g}$ of Spirulina platensis biomass was placed in Petri dishes, protected from light with foil, and submitted to temperatures of $25^{\circ} \mathrm{C}, 40^{\circ} \mathrm{C}$ or $50^{\circ} \mathrm{C}$ for 60 days, in the dark, protected from light. Samples were taken every 7 days for the determination of the antioxidant potential of the powders.

In the photo stability study, the microalgae powder was conditioned in gelatin capsules (transparent) and amber glass, placed directly into Petri dishes and then exposed to a UV lamp (Philips, $15 \mathrm{~W}, \lambda=265 \mathrm{~nm}$ ) and a fluorescent lamp (Taschibra, $20 \mathrm{~W}, 0.16 \mathrm{~A}$, power factor $\mathrm{FP}>0.5,50 / 60 \mathrm{~Hz}, 60 \mathrm{~lm} / \mathrm{w}, 1200 \mathrm{~lm}$ ), which was arranged in a chamber of $0.7 \mathrm{~m}^{2}$, internally lined with foil. These experiments were accomplished at room temperature. Samples were taken every 30 days for the determination of the antioxidant potential of the powders.

\subsection{Antioxidant Potential (AP) evaluation}

The AP of the Spirulina powder samples was evaluated in a lipid system consisting of soybean oil, according to the methodology proposed by Souza et al. (2006). In $1000 \mathrm{~mL}$ beakers, $250 \mathrm{~mL}$ of soybean oil and $1 \mathrm{~g}$ of Spirulina platensis powder were added. The system was homogenized with a magnetic stirrer. The oxidation of the lipid system was induced by heating at $80^{\circ} \mathrm{C}$ and aeration from a diaphragm pump for $10 \mathrm{~h}$. Samplings were carried out at the beginning $(0 \mathrm{~h})$ and the end $(10 \mathrm{~h})$ for the determination of the peroxide index (IP) (Araújo, 2008). The determinations were performed in triplicate.

A control experiment of soybean oil oxidation without the addition of $S$. platensis powder was conducted to evaluate the peroxidation of soybean oil in the absence 
of the antioxidant provided by the $S$. platensis powder. The IP was calculated using the Equation 1.

$$
I P=\left(V-V_{b}\right) \cdot N \cdot 1000 / m
$$

Where: $\mathrm{V}$ is the volume ( $\mathrm{mL}$ ) of sodium thiosulfate spent in the titration of the oil with Spirulina powder; $\mathrm{V}_{\mathrm{b}}$ is the volume $(\mathrm{mL})$ of sodium thiosulfate spent in the titration of the oil without the addition of $S$. platensis powder; $\mathrm{N}$ is the normality of the standardized sodium thiosulfate; and $\mathrm{m}$ is the mass of $S$. platensis powder used in the test.

The AP was calculated using Equation 2, with the results of the IP of soybean oil being subjected to oxidation in the presence and absence of microalgae powder.

$$
A P(\%)=\frac{I P_{S O}-I P_{(S O-S)}}{I P_{S O}} .100
$$

where

$$
\begin{aligned}
& I P_{S O}=I P_{S O 10 h}-I P_{S O O h} \\
& I P_{(S O-S)}=I P_{(S O-S) 10 h}-I P_{(S O-S) 0 h}
\end{aligned}
$$

$\mathrm{IP}_{\mathrm{SO}}$ is the peroxide index of soybean oil without Spirulina powder at 10 hours and 0 hours of oxidation, and $\mathrm{IP}_{\text {so-s }}$ is the peroxide index of soybean oil with Spirulina powder at 10 hours and 0 hours of oxidation.

\subsection{Determination of kinetic parameters}

The Arrhenius method was used to determine the kinetics of thermal degradation. Through the data obtained, the kinetic of degradation of AP was determined by analyzing the reaction order and using the degradation rate constant $(\mathrm{K})$ from Equation 3, where " $\mathrm{n}$ " is the reaction order.

$$
\frac{d(A P)}{d t}=-K \cdot(A P)^{n}
$$

To define the order of the reaction, the AP obtained over time was plotted in the following forms: the AP as a function of time (zero order), the logarithm of AP versus time (first order) and the reverse AP versus time (second order). The determinations coefficients $\left(\mathrm{R}^{2}\right)$ obtained in each plot were used to determine the reaction order for each temperature, considering the best straight line obtained (Carstensen and Rhodes, 2000). The same procedure was used to determine the order of the photo degradation of the $S$. platensis powder packaged in each storage form.

Equation 4 was obtained from the integration of Equation 3 to zero order kinetics, providing the degradation rate constant for a zero order $\left(\mathrm{K}_{0}\right)$ reaction.

$$
K_{0}=\left(A P_{\text {initial }}-A P_{t}\right) / t
$$

where $\mathrm{AP}_{\text {initial }}$ is the value of $\mathrm{AP}$ obtained at initial time $(\%)$; $\mathrm{AP}_{\mathrm{t}}$ is the value of AP measured in time $\mathrm{t}(\%)$; and $\mathrm{T}$ is the oxidation time $(\mathrm{h})$.

The half-life $\left(\mathrm{t}_{50 \%}\right)$ can be calculated from Equation 5 (zero order) as the time required for a $50 \%$ loss of AP.

$t_{50 \%}=A P_{\text {initial }} / 2 K_{0}$
The shelf life $\left(\mathrm{t}_{90 \%}\right)$ consists of the time required for a $10 \%$ degradation and is calculated using Equation 6 (zero order).

$t_{90 \%}=0.1 . A P_{\text {initial }} / K_{0}$

\subsection{Statistical analysis}

The AP results were submitted to ANOVA, and the means were compared using Tukey's test and a confident interval of $95 \%$, using the software Assistat 7.7.

\section{Results}

A higher value of IP in the oxidation of soybean oil without $S$. platensis powder was observed after $10 \mathrm{~h}$ of oxidation $(64.7 \pm 0.61 \mathrm{meq} / \mathrm{kg})$. In the beginning of the oxidation process of the soybean oil, the IP was $3.4 \pm 0.42 \mathrm{meq} / \mathrm{kg}$. The IP of soybean oil using S. platensis powder before the degradation process by heat or light was $5.1 \pm 0.01 \mathrm{meq} / \mathrm{kg}$ and $0.9 \pm 0.12 \mathrm{meq} / \mathrm{kg}$ at $0 \mathrm{~h}$ and $10 \mathrm{~h}$ of oxidation, respectively.

The AP results (\%) of the $S$. platensis stored at $25^{\circ} \mathrm{C}$, $40^{\circ} \mathrm{C}$ and $50^{\circ} \mathrm{C}$ over time are presented in Table 1 . There was a statistically significant difference $(p<0.05)$ in the AP obtained at all temperatures tested. However, we can't predict about the behavior in intermediates temperatures between those tested.

Table 2 presents the AP obtained for the $S$. platensis powder samples stored in Petri dishes, transparent capsules and amber glasses in the photo stability studies after their exposure to UV or fluorescent light for 90 days.

It is important to note that the mass used in light or thermal conditions were different, in this way, the treatments applied to a mass are limited by the power of penetration of heat or electromagnetic radiation. This effect has not been evaluated in our study.

The graphics of the AP (\%), log AP and 1/AP versus time (days) were generated for all experiments performed, providing a linear determination coefficient $\left(\mathrm{R}^{2}\right)$. A value

Table 1. Antioxidant potential (\%) of Spirulina platensis powder stored with exposure to temperatures of $25{ }^{\circ} \mathrm{C}$, $40^{\circ} \mathrm{C}$ and $50^{\circ} \mathrm{C}(\mathrm{n}=3 \pm$ standard deviation $)$.

\begin{tabular}{cccc}
\hline \multirow{2}{*}{$\begin{array}{c}\text { Time } \\
\text { (days) }\end{array}$} & \multicolumn{3}{c}{ Antioxidant potential (\%)* } \\
\cline { 2 - 4 } & $\mathbf{2 5}^{\circ} \mathbf{C}$ & $\mathbf{4 0}^{\circ} \mathbf{C}$ & $\mathbf{5 0}^{\circ} \mathbf{C}$ \\
\hline 0 & $93.2 \pm 0.17^{\mathrm{a}}$ & $93.2 \pm 0.17^{\mathrm{a}}$ & $93.2 \pm 0.17^{\mathrm{a}}$ \\
7 & $83.1 \pm 0.04^{\mathrm{a}}$ & $83.0 \pm 0.04^{\mathrm{b}}$ & $69.6 \pm 0.02^{\mathrm{c}}$ \\
14 & $83.0 \pm 0.04^{\mathrm{a}}$ & $74.9 \pm 0.23^{\mathrm{b}}$ & $51.9 \pm 0.90^{\mathrm{c}}$ \\
21 & $82.5 \pm 0.31^{\mathrm{a}}$ & $61.0 \pm 0.04^{\mathrm{b}}$ & $37.0 \pm 0.05^{\mathrm{c}}$ \\
28 & $82.3 \pm 0.08^{\mathrm{a}}$ & $60.3 \pm 0.05^{\mathrm{b}}$ & $28.6 \pm 0.17^{\mathrm{c}}$ \\
35 & $69.8 \pm 1.33^{\mathrm{a}}$ & $46.2 \pm 0.35^{\mathrm{b}}$ & $27.7 \pm 0.19^{\mathrm{c}}$ \\
42 & $62.2 \pm 0.05^{\mathrm{a}}$ & $35.7 \pm 0.62^{\mathrm{b}}$ & $18.7 \pm 0.09^{\mathrm{c}}$ \\
49 & $55.6 \pm 0.76^{\mathrm{a}}$ & $29.6 \pm 0.09^{\mathrm{b}}$ & $11.1 \pm 0.14^{\mathrm{c}}$ \\
56 & $45.6 \pm 0.26^{\mathrm{a}}$ & $19.8 \pm 0.03^{\mathrm{b}}$ & $1.7 \pm 0.17^{\mathrm{c}}$ \\
63 & $30.7 \pm 0.08^{\mathrm{a}}$ & $10.2 \pm 0.12^{\mathrm{b}}$ & $0^{\mathrm{c}}$ \\
\hline
\end{tabular}

*Means followed by different letters in the same line differ significantly (Tukey test, $\mathrm{p}<0.05$ ). 
of $\mathrm{R}^{2}$ close to 1 defined the order of degradation reaction in the thermal degradation and photo stability studies (Table 3 ). The highest values of $\mathrm{R}^{2}$ for all temperatures were observed in the graph of AP (\%) versus time (days) of storage, suggesting that the kinetics of thermal degradation followed a zero order reaction. As for photo stability, the highest values of $\mathrm{R}^{2}$ were observed after plotting the data of log AP (\%) by time (days) of storage, suggesting that the degradation kinetics followed a first order reaction.

The degradation rate constant $(\mathrm{K})$, as well as the time for reduction of $50 \%\left(\mathrm{t}_{50 \%}\right)$ and $10 \%\left(\mathrm{t}_{90 \%}\right)$ of the AP in the experiments with thermal degradation are presented in Table 4. As for the thermal stability study, the half-life $\left(\mathrm{t}_{50 \%}\right)$ ranged from 20 to 52 days, and the shelf life $\left(\mathrm{t}_{90 \%}\right)$ was less than 11 days in all cases.

\section{Discussion}

Comparing the results of the IP of soybean oil oxidized for 10 hours with or without the $S$. platensis powder as an antioxidant, it can be observed that the maximum AP obtained was $93.1 \%$ when powder with no exposure to thermal or photo degradation was used. This finding demonstrates that the $S$. platensis powder is able to delay the oxidation process and reduce the formation of peroxides, effectively acting as an antioxidant in the lipid system. Soybean oil contains a large amount of unsaturated fatty acids, including oleic, linoleic and linolenic acids, and as such, it is easily oxidized through a number of desaturations, acting as a decisive factor for the reaction rate of lipid peroxidation (Araújo, 2008).
Regarding the choice of the methodology to determine the antioxidant potential, it was chosen according to the ease of implementation and technical simplicity, and the fact that allowed the addition of the entire biomass in a lipid system (vegetable oil of low cost), without the need of extractions, allowing verify the effect of all antioxidant present in biomass.

The thermal stability evaluation showed that the degradation of $S$. platensis powder was higher at $50^{\circ} \mathrm{C}$, and after 63 days, the AP was completely degraded. At $25^{\circ} \mathrm{C}$, the $S$. platensis powder demonstrated the highest stability, followed by $40^{\circ} \mathrm{C}$. AP is clearly highly sensitive to temperature as even at $25^{\circ} \mathrm{C}$, there was a decrease of AP.

The evaluation of the chemical kinetics and the reaction orders can determine the knowledge of the degradation profile or concentration-time profile of a given substance (Carstensen and Rhodes, 2000). The kinetics of thermal degradation was determined using the Arrhenius method, even considering the Spirulina powder a complex material. Others authors used this model in pharmaceutical formulations (considered complex) (Slater et al., 1979; Siddiqui et al., 2011; Shabbeer and Aly, 2014). As for thermal stability, the kinetics degradations in all temperatures were of the zero order, for which the degradation rate is independent of the concentration of the reactants; i.e., the reaction rate of degradation is constant.

El-Baky et al. (2008) quantify the major compounds with antioxidant activity at Spirulina maxima growing in Zarrouk with different concentrations of nitrogen, and found that the amount of phycocyanin ranging from 45.3 to $106.4 \mathrm{mg} / \mathrm{g}$, while tocopherol ranged from 0.266 to $1.32 \mathrm{mg} / \mathrm{g}$, total

Table 2. Antioxidant potential (\%) of Spirulina platensis powder stored with exposure to UV and fluorescent light $(\mathrm{n}=3 \pm$ standard deviation).

\begin{tabular}{|c|c|c|c|c|c|c|}
\hline \multirow{3}{*}{$\begin{array}{l}\text { Time } \\
\text { (days) }\end{array}$} & \multicolumn{6}{|c|}{ Antioxidant Potential (\%)* } \\
\hline & \multicolumn{3}{|c|}{ UV light } & \multicolumn{3}{|c|}{ Fluorescent light } \\
\hline & Plate* & Capsule* & Glass* & Plate* & Capsule* & Glass* \\
\hline $\mathbf{0}$ & $93.1^{\mathrm{a}} \pm 0.20$ & $93.1^{\mathrm{a}} \pm 0.20$ & $93.1^{\mathrm{a}} \pm 0.20$ & $93.1^{\mathrm{a}} \pm 0.20$ & $93.1^{\mathrm{a}} \pm 0.20$ & $93.1^{\mathrm{a}} \pm 0.20$ \\
\hline 30 & $32.1^{\mathrm{e}} \pm 0.22$ & $40.1^{\mathrm{d}} \pm 0.27$ & $47.4^{b} \pm 0.25$ & $39.9^{\mathrm{d}} \pm 0.27$ & $45.4^{\mathrm{c}} \pm 0.21$ & $50.0^{\mathrm{a}} \pm 0.18$ \\
\hline 60 & $4.5^{\mathrm{f}} \pm 0.32$ & $7.9^{\mathrm{d}} \pm 0.21$ & $13.0^{\mathrm{b}} \pm 0.22$ & $6.6^{\mathrm{e}} \pm 0.37$ & $16.5^{\mathrm{a}} \pm 0.31$ & $12.0^{\mathrm{c}} \pm 0.23$ \\
\hline 90 & $0^{\mathrm{d}}$ & $0^{\mathrm{d}}$ & $0^{\mathrm{d}}$ & $1.3^{c} \pm 0.38$ & $12.2^{\mathrm{a}} \pm 0.29$ & $3.4^{\mathrm{b}} \pm 0.41$ \\
\hline
\end{tabular}

*Means followed by different letters in the same line differ significantly (Tukey test, $\mathrm{p}<0.05$ ).

Table 3. Correlation coefficient $\left(\mathrm{R}^{2}\right)$ of the degradation kinetics of the antioxidant potential of Spirulina platensis powder in thermal and photo stability studies.

\begin{tabular}{ccccc}
\hline \multicolumn{2}{c}{ Storage conditions } & $\mathbf{R}^{2}$ Zero order & $\mathbf{R}^{2}$ First order & $\mathbf{R}^{2}$ Second order \\
\hline \multirow{3}{*}{ Temperature } & $25{ }^{\circ} \mathrm{C}$ & 0.9064 & 0.8293 & 0.7165 \\
& $40{ }^{\circ} \mathrm{C}$ & 0.9938 & 0.9094 & 0.6694 \\
& $50{ }^{\circ} \mathrm{C}$ & 0.9702 & 0.8573 & 0.5686 \\
\hline \multirow{2}{*}{ UV Light } & Petry dishes & 0.9547 & 0.9714 & 0.8215 \\
& Capsule & 0.9505 & 0.9677 & 0.8407 \\
& Glass & 0.9534 & 0.9681 & 0.8638 \\
\hline \multirow{3}{*}{ Fluorescent Light } & Petry dishes & 0.8920 & 0.9797 & 0.7365 \\
& Capsule & 0.8866 & 0.9646 & 0.9624 \\
& Glass & 0.9350 & 0.9775 & 0.7971 \\
\hline
\end{tabular}


Table 4. $\mathrm{K}, \mathrm{t}_{50 \%}$ and $\mathrm{t}_{90 \%}$ values of the degradation kinetics of the antioxidant potential of Spirulina platensis powder in the thermal stability studies.

\begin{tabular}{ccccc}
\hline Storage conditions & $\begin{array}{c}\mathbf{K} \\
\text { (days }^{-1} \text { ) }\end{array}$ & $\begin{array}{c}\mathbf{t}_{\mathbf{5 0 \%}} \\
\text { (days) }\end{array}$ & $\begin{array}{c}\mathbf{t}_{\mathbf{9 0} \%} \\
\text { (days) }\end{array}$ \\
\hline \multirow{3}{*}{ Temperature } & $25{ }^{\circ} \mathrm{C}$ & 0.89 & 52 & 11 \\
& $40{ }^{\circ} \mathrm{C}$ & 1.30 & 36 & 7 \\
& $50{ }^{\circ} \mathrm{C}$ & 2.31 & 20 & 4 \\
\hline
\end{tabular}

phenol varied of 3.08 to $4.98 \mathrm{mg} / \mathrm{g}$ and the chlorophyll of 7.69 to $16.23 \mathrm{mg} / \mathrm{g}$. Other phenolic compounds were described for Spirulina platensis, as pyrogallol, gallic, p-OH benzoic, catechol, caffeic, protocatechouic, catechin, chlorogenic, vanillic, synergic, caffeine, ferulic, salicylic and coumarin (Shalaby and Shanab, 2013). Because of that, we considered that one of the most important component, responsible for the antioxidant activity is the phycocyanin. But, as the whole biomass was used, the others components (included phenolic compounds) probably influenced too. The measure of antioxidant potential was taken as an indicative of the effects of temperature and luminosity over the compounds with antioxidant activity, mainly phycocyanin.

Phycocyanin is a phicobiliprotein present in the composition of the Spirulina biomass. This compound, is used as a food coloring and has a great antioxidant (Patel et al., 2006; Sonani et al., 2015), anti-inflammatory, immunomodulatory and anti-cancer properties (Hirata et al., 2000; Romay et al., 2003; Patel et al., 2004; Eriksen, 2008). Sarada et al. (1999) studied the stability of phycocyanin, and observed stability for 4 weeks in a $\mathrm{pH}$ range of $5-7.5$ at $25^{\circ} \mathrm{C}$ and $9^{\circ} \mathrm{C}$. Above and below the $\mathrm{pH}$ range of $5-7.5$, the pigment gradually lost its color, due to its chemical character with chromophores groups, carboxylic acid and amines, that can receive or donate protons depending on the medium in which they are. Phycocyanin was unstable above $45^{\circ} \mathrm{C}$, and its color decreased at just 1 day. At $10^{\circ} \mathrm{C}$ and $4^{\circ} \mathrm{C}$, phycocyanin was stable for long periods.

Chaiklahan et al. (2012) evaluated the effect of temperature, $\mathrm{pH}$ and the addition of preservatives in phycocyanin solutions. The phycocyanin solution followed first order degradation kinetics. At $59^{\circ} \mathrm{C}$, the concentration of phycocyanin was reduced by approximately $50 \%$ over $30 \mathrm{~min}$, and at $60^{\circ} \mathrm{C}$ after the addition of sodium chloride $(2.5 \%)$ the concentration of phycocyanin was maintained at $76 \%$, increasing the half-life from $19 \mathrm{~min}$ to $67 \mathrm{~min}$.

Antelo et al. (2008) evaluated the degradation of the phycocyanin solution. The degradation followed first order kinetics. Between 50 and $55^{\circ} \mathrm{C}$, the solution was more stable at $\mathrm{pH} 6$; between 57 and $65^{\circ} \mathrm{C}$, the solution was stable at $\mathrm{pH} 5$, in effect becoming decreasingly stable at $\mathrm{pH} 7$ as the temperature increased. The addition of sorbitol $10-50 \%(\mathrm{w} / \mathrm{w})$ increased the half-life of the solutions of phycocyanin, indicating that discoloration is related to the degradation of the protein chain after the sorbitol stabilizes the proteins.
The S. platensis and S. maxima biomasses contain gamma linolenic acid (Vonshak, 1997), which are polyunsaturated long-chain fat acids involved in many functional biologic pathways, such as the growth and maintenance of the skin and hair and the regulation of cholesterol metabolism (Gerster, 1995; Gill and Valivety, 1997). The half-life of the Spirulina, as based on the degradation of $20 \%$ of GLA using the Arrhenius plot, was 8.6 months at $30^{\circ} \mathrm{C}$. The degradation reaction of GLA followed first order kinetics, for which the degradation rate depends on the remaining amount of GLA (Tiburcio et al., 2007).

The above mentioned studies were performed using compounds extracted from Spirulina, such as the phycocyanin and GLA. Comparing the results obtained after the thermal degradation of our work with the aforementioned, it can be inferred that the AP observed in the soybean oil lipid system is being generated by phycocyanin and other compounds due to the potential for instability when the biomass is stored at temperatures above $40^{\circ} \mathrm{C}$. As observed in the abovementioned works, phycocyanin is more unstable than the GLA. In our study, we evaluated the AP of microalgae as a whole and used biomass in the form of powder, unlike reports involving solutions of single compounds. These stipulations explain the fact that, in this work, we found a degradation rate of the zero order. We observed that Spirulina in powder form is easily degraded when exposed to heat and should be stored at temperatures below $10^{\circ} \mathrm{C}$.

In the photo stability study, for both sources of light, the degradation kinetics was of first order, for which the rate of degradation is dependent on the concentration of the reactants.

The results obtained show that the AP of $S$. platensis powder decreases considerably in both fluorescent and UV light, with the greater degradation observed in the UV light as this type of illumination contains more energy with more penetrating power. In the UV light, degradation occurred in the following ascending order: Petri dishes, capsules, and glass. This behavior was similar under fluorescent lights, whereas after 60 to 90 days of degradation, the amount observed in the glass was greater than in the capsules. Of the three storage situations generating degradation, the glass ensured the best conditions for conservation and protection in the first 30 days (antioxidant potential close to $50 \%$ ) in both types of light; after this point, the degradation was similar to that occurring in the capsules. In the Petri dishes, the reduction of AP occurred much more quickly as this mode offered no protection.

After 2 months of exposure to the light sources, the amount of antioxidant compounds present in the samples totaled less than $30 \%$, demonstrating that the use of microalgae for human consumption as an antioxidant is not justified, if not properly stored. Nevertheless, microalgae present other beneficial substances whose behaviors under the light storage conditions were not assessed in this study, such as proteins, vitamins and minerals. The packaging materials used in the UV light and fluorescent light provided significantly different results from one another at all times. In this way, the light and inadequate storage 
conditions are factors in the degradation of the antioxidant compounds from microalgae.

Under the influence of light, Zhou et al. (2005) determined the ability of phycocyanin to eliminate hydroxyl radicals in both the light and dark and the removal was much lower in the light because phycocyanin generates hydroxyl radicals in the light rather than eliminating them. It was also observed that high concentrations of phycocyanin did not generate hydroxyl radicals, whereas light exposure for low concentrations of phycocyanin facilitated the generation of these radicals. This ability to eliminate hydroxyl radicals was increased after the denaturation of the protein phycocyanin complex, as well as when the $\mathrm{pH}$ increased. Phycocyanins can absorb and transfer light energy when their natural structure containing apoprotein is maintained; however, when the aim is the removal of the hydroxyl radical, the use of the denatured structure is ideal.

In another study, phycocyanin was proved to be unstable in conditions of heat and light in an aqueous solution, and light exposure for 24 hours in an aqueous solution of $\mathrm{pH} 5$ resulted in approximately an $80 \%$ degradation (Jespersen et al., 2005).

\section{Conclusion}

This work allows us to infer that the AP of S. platensis in solid form is easily degraded when exposed to heat and light, demonstrating degradation more than $50 \%$ after 30 day of exposition in most cases studied. The results indicate that microalgae should be stored in packs that protect these processes, namely at temperatures below $10^{\circ} \mathrm{C}$ in amber packs that are hermetically sealed, particularly when the therapeutic indications are related to antioxidant activity. Spirulina microalgae are widely sold in pharmacies as slimming aids. For this product to also be consumed as an antioxidant, adequate storage conditions must be considered due to the thermal and photolytic instability of phycocyanin.

\section{References}

AMBROSI, M.A., REINEHR, C.O., BERTOLIN, T.E., COSTA, J A.V. and COLLA, L.M., 2008. Propriedades de saúde de Spirulina spp. Revista de Ciências Farmacêuticas Básica e Aplicada, vol. 29, no. 2, pp. 109-117.

ANTELO, F.S., COSTA, J.A.V. and KALIL, S.J., 2008. Thermal degradation kinetics of the phycocyanin from Spirulina platensis. Biochemical Engineering Journal, vol. 41, no. 1, pp. 43-47. http:// dx.doi.org/10.1016/j.bej.2008.03.012.

ARAÚJO, J.M.A., 2008. Química de alimentos: teoria e prática. 4th ed. Viçosa: UFV.

BECKER, E.W., JAKOBER, B., LUFT, D. and SCHMILLING, R.W., 1986. Clinical and biochemical evaluations of Spirulina with regard to its application in the treatment of obesity. Nutrition Reports International, vol. 33, no. 4, pp. 565-574.

BELAY, A., OTA, Y., MIYAKAWA, K. and SHIMAMATSU, H., 1993. Current knowledge on potential health benefits of Spirulina.
Journal of Applied Phycology, vol. 5, no. 2, pp. 235-241. http:// dx.doi.org/10.1007/BF00004024.

BENITES, R.S.R., FORMAGIO, A.S.N., ARGANDOÑA, E.J.S., VOLOBUFF, C.R.F., TREVIZAN, L.N.F., VIEIRA, M.C. and SILVA, M.S., 2015. Contents of constituents and antioxidant activity of seed and pulp extracts of Annona coriacea and Annona sylvatica. Brazilian Journal of Biology = Revista Brasileira de Biologia, vol. 75, no. 3, pp. 685-691. http://dx.doi. org/10.1590/1519-6984.21313. PMid:26421762.

BERTOLIN, T.E., FARIAS, D., GUARIENTI, C., PETRY, F.T.S., COLLA, L.M. and COSTA, J.A.V., 2011. Antioxidant effect of phycocyanin on oxidative stress induced with monosodium glutamate in rats. Brazilian Archives of Biology and Technology, vol. 54, no. 4, pp. 733-738. http://dx.doi.org/10.1590/S151689132011000400012 .

BERTOLIN, T.E., PILATTI, D., GIACOMINI, A.C.V.V., BAVARESCO, C.S., COLLA, L.M. and COSTA, J.A.V., 2009. Effect of microalga Spirulina platensis (Arthrospira platensis) on hippocampus lipoperoxidation and lipid profile in rats with induced hypercholesterolemia. Brazilian Archives of Biology and Technology, vol. 52, no. 5, pp. 1253-1259. http://dx.doi. org/10.1590/S1516-89132009000500024.

BITTENCOURT-OLIVEIRA, M.C., HEREMAN, T.C., MACEDOSILVA, I., CORDEIRO-ARAÚJO, M.K., SASAKI, F.F. and DIAS, C.T., 2015. Sensitivity of salad greens (Lactuca sativa L. and Eruca sativa Mill.) exposed to crude extracts of toxic and non-toxic cyanobacteria. Brazilian Journal of Biology $=$ Revista Brasileira de Biologia, vol. 75, no. 2, pp. 273-278. http://dx.doi. org/10.1590/1519-6984.08113. PMid:26132007.

BRASIL, Agência Nacional de Vigilância Sanitária, 2005. Resolução RE $n^{\circ} 1$, de 29 de julho de 2005. Dispõe sobre o Guia para a Realização de Estudos de Estabilidade. Diário Oficial da República Federativa do Brasil, Brasília, 8 ago. Seção 1, pp. 119.

BRASIL, Agência Nacional de Vigilância Sanitária, 2013 [viewed 27 May 2013]. VII Lista dos novos ingredientes aprovados [online]. Brasília: Comissões Tecno-científicas de Assessoramento em Alimentos Funcionais e Novos Alimentos. Available from: http:// www.anvisa.gov.br/alimentos/comissoes/novos_ingredientes.htm

CARSTENSEN, J.T. and RHODES, C.T., 2000. Drug stability: principles and practices. 3rd ed. New York: Marcel Dekker.

CHAIKLAHAN, R., CHIRASUWAN, N. and BUNNAG, B., 2012. Stability of phycocyanin extracted from Spirulina sp.: Influence of temperature, $\mathrm{pH}$ and preservatives. Process Biochemistry, vol. 47, no. 4, pp. 659-664. http://dx.doi.org/10.1016/j.procbio.2012.01.010.

COLLA, L.M., BERTOLIN, T.E. and COSTA, J.A.V., 2004. Fatty acids profile of Spirulina platensis grown under different conditions as compared with that of commercially produced Spirulina. Zeitschrift für Naturforschung, vol. 59C, pp. 55-59. PMid:15018053.

COLLA, L.M., MUCCILLO-BAISCH, A.L. and COSTA, J.A.V., 2008. Spirulina platensis effects on the levels of total cholesterol, HDL cholesterol and triglycerides in rabbits fed with a hypercholesterolemic diet. Brazilian Archives of Biology and Technology, vol. 51, no. 2, pp. 405-411. http://dx.doi.org/10.1590/ S1516-89132008000200022.

COLLA, L.M., REINEHR, C.O., REICHERT, C. and COSTA, J.A.V., 2007. Production of biomass, lipids, phenolic compounds and proteins by Spirulina platensis under different temperature and nitrogen regimes. Bioresource Technology, vol. 98, pp. 
1489-1493. http://dx.doi.org/10.1016/j.biortech.2005.09.030. PMid: 17070035.

DONATO, N.R., SILVA, J.A., COSTA, M.J.C., BARBOSA, M.Q., BION, F.M., CARVALHO-FILHO, E.V., VERAS, R.C. and MEDEIROS, I.A., 2010. Uso da Spirulina platensis na recuperação de ratos submetidos à dieta de restrição proteica. Revista do Instituto Adolfo Lutz, vol. 69, no. 1, pp. 69-77.

EL-BAKY, H.H.A., EL BAZ, F.K. and EL-BAROTY, G.S., 2008. Characterization of nutraceutical compounds in blue green alga Spirulina maxima. Journal of Medicinal Plants Research, vol. 2, no. 10, pp. 292-300.

EL-SHEEKH, M.M., DABOOR, S.M., SWELIM, M.A. and MOHAMED, S., 2014. Production and characterization of antimicrobial active substance from Spirulina platensis. Iranian Journal of Microbiology, vol. 6, no. 2, pp. 112-119. PMid:25705362.

ERIKSEN, N.T., 2008. Production of phycocyanin - a pigment with applications in biology, biotechnology, foods and medicine. Applied Microbiology and Biotechnology, vol. 80, no. 1, pp. 1-14. http://dx.doi.org/10.1007/s00253-008-1542-y. PMid:18563408.

FORMAGIO, A.S.N., RAMOS, D.D., VIEIRA, M.C., RAMALHO, S.R., SILVA, M.M., ZÁRATE, N.A.H., FOGLIO, M.A. and CARVALHO, J.E., 2015. Phenolic compounds of Hibiscus sabdariffa and influence of organic residues on its antioxidant and antitumoral properties. Brazilian Journal of Biology $=$ Revista Brasileira de Biologia, vol. 75, no. 1, pp. 69-76. http://dx.doi. org/10.1590/1519-6984.07413. PMid:25945622.

GERSTER, H., 1995. The use of n-3 PUFAs (fish oil) in enteral nutrition. International Journal for Vitamin and Nutrition Research, vol. 65, no. 1, pp. 3-20. PMid:7657477.

GILL, I. and VALIVETY, R., 1997. Polyunsaturated fatty acids, Part 1: occurrence, biological activities and applications. Trends in Biotechnology, vol. 15, no. 10, pp. 401-409. http://dx.doi. org/10.1016/S0167-7799(97)01076-7. PMid:9351284.

GUARIENTI, C., BERTOLIN, T.E., and COSTA, J.A.V., 2010. Capacidade antioxidante da microalga Spirulina platensis em células da levedura Saccharomyces cerevisiae submetidas ao estressor paraquat. Revista do Instituto Adolfo Lutz, vol. 69, pp. 56-62.

HENRIKSON, R., 1995. Microalga Spirulina: superalimento del futuro. Barcelona: Ediciones Urano S.A.

HIRATA, T., TANAKA, M., OOIKE, M., TSUNOMURA, T. and SAKAGUCHI, M., 2000. Antioxidant activities of phycocyanobilin prepared from Spirulina platensis. Journal of Applied Phycology, vol. 12, no. 3/5, pp. 435-439. http://dx.doi. org/10.1023/A:1008175217194.

JAIME, L., MENDIOLA, J.A., HERRERO, M., SOLERRIVAS, C., SANTOYO, S., SEÑORANS, F.J., CIFUENTES, A. and IBÁÑEZ, E., 2005. Separation and characterization of antioxidants from Spirulina platensis microalga combining pressurized liquid extraction, TLC, and HPLC-DAD. Journal of Separation Science, vol. 28, no. 16, pp. 2111-2119. http://dx.doi. org/10.1002/jssc.200500185. PMid:16318207.

JESPERSEN, L., STRØMDAHL, L.D., OLSEN, K. and SKIBSTED, L.H., 2005. Heat and light stability of three natural blue colorants for use in confectionery and beverages. European Food Research and Technology, vol. 220, no. 3-4, pp. 261-266. http://dx.doi.org/10.1007/s00217-004-1062-7.

KAUSHIK, P. and CHAUHAN, A., 2008. In vitro antibacterial activity of laboratory grown culture of Spirulina platensis. Indian
Journal of Microbiology, vol. 48, no. 3, pp. 348-352. http://dx.doi. org/10.1007/s12088-008-0043-0. PMid:23100733.

KUMAR, V., BHATNAGAR, A.K. and SRIVASTAVA, J.N., 2011. Antibacterial activity of crude extracts of Spirulina platensis and its structural elucidation of bioactive compound. Journal of Medicinal Plants Research, vol. 5, no. 32, pp. 7043-7048.

MALA, R., SAROJINI, M., SARAVANABABU, S. and UMADEVI, G., 2009. Screening for antimicrobial activity of crude extracts of Spirulina platensis. Journal of Cell and Tissue Research, vol. 9, no. 3, pp. 1951-1955.

MOURA, L.P., GURJÃO, A.L.D., JAMBASSI FILHO, F.C., MIZUNO, J., SUEMI, C. and MELLO, M.A.R., 2012. Spirulina, exercício e controle da glicemia em ratos diabéticos. Arquivos Brasileiros de Endocrinologia e Metabologia, vol. 56, no. 1, pp. 25-32. http://dx.doi.org/10.1590/S0004-27302012000100005. PMid:22460192.

PARISI, A.S., YOUNES, S., REINEHR, C.O. and COLLA, L.M., 2009. Avaliação da atividade antibacteriana da microalga Spirulina platensis. Revista de Ciências Farmacêuticas Básica e Aplicada, vol. 30, pp. 297-301.

PATEL, A., MISHRA, S. and GHOSH, P.K., 2006. Antioxidant potential of C-Phycocyanin isolated from three cyanobacterial species: Lyngbya, Phormidium and Spirulina spp. Indian Journal of Biochemistry \& Biophysics, vol. 43, no. 1, pp. 31-35. PMid:16955748.

PATEL, A., PAWAR, R., MISHRA, S., SONAWANE, S. and GHOSH, P.K., 2004. Kinetic studies on thermal denaturation of C-Phycocyanin. Indian Journal of Biochemistry \& Biophysics, vol. 41, no. 5, pp. 254-257. PMid:22900283.

PEREZ, K.J., GUARIENTI, C., BERTOLIN, T.E., COSTA, J A.V. and COLLA, L.M., 2007. Viabilidade de bactérias láticas em iogurte adicionado de biomassa da microalga Spirulina platensis durante o armazenamento refrigerado. Alimentos e Nutrição, vol. 18 , no. 1 , pp. $77-82$.

PÉREZ, L.V., ABRAHAM, C.M., LEYVA, I.T., FERRER, B.B.S., SUÁREZ, V.M. and SEGURA, M.S., 2002 [viewed 18 March 2013]. Efecto in vitro de la espirulina sobre la respuesta inmune. Revista Cubana de Hematologia, Inmunologia e Hemoterapia [online], vol. 18, no. 2. Available from: http://bvs.sld.cu/revistas/ hih/vol18_2_02/hih06202.htm

RICHMOND, A., 1990. Handbook of microalgal mass culture. Boston: CRC Press.

ROMAY, C.H., GONZÁLEZ, R., LEDÓN, N., REMIREZ, D. and RIMBAU, V., 2003. C-phycocyanin: a biliprotein with antioxidant, anti-inflammatory and neuroprotective effects. Current Protein \& Peptide Science, vol. 4, no. 3, pp. 207-216. http://dx.doi.org/10.2174/1389203033487216. PMid:12769719.

SARADA, D.V.L., KUMAR, C.S. and RENGASAMY, R., 2011. Purified C-phycocyanin from Spirulina platensis (Nordstedt) Geitler: a novel and potent agent against drug resistant bacteria. World Journal of Microbiology \& Biotechnology, vol. 27, no. 4, pp. 779-783. http://dx.doi.org/10.1007/s11274-010-0516-2.

SARADA, R., PILLAI, M.G. and RAVISHANKAR, G.A., 1999. Phycocyanin form Spirulina sp.: influence of processing of biomass on phycocyanin yield, analysis of efficacy ofextraction methods and stability studies on phycocyanin. Process Biochemistry, vol. 34, no. 8, pp. 795-801. http://dx.doi.org/10.1016/S00329592(98)00153-8. 
SHABBEER, F.A. and ALY, S.A.S., 2014. Evaluation of dislubtout, a new coprocessed tableting excipient 3 . Physico-chemical properties of wet granulation aspirin tablets lubricated with dislub-tout. European Scientific Journal, vol. 10, no. 30, pp. 417-426.

SHALABY, E.A. and SHANAB, S.M.M., 2013. Comparison of DPPH and ABTS assays for determining antioxidant potential of water and methanol extracts of Spirulina platensis. Indian Journal of Geo-Marine Sciences, vol. 42, no. 5, pp. 556-564.

SIDDIQUI, N., HUSAIN, A., CHAUDHARY, L., MITRA, M. and BHASIN, P.S., 2011. Stability, degradation kinetics and in vitro bioequivalence studies of valsartan tablets. Current Pharma Research, vol. 2, no. 1, pp. 389-395.

SILVA, L.A., 2008. Estudo do processo biotecnológico de produção, extração e recuperação do pigmento ficocianina da Spirulina platensis. Curitiba: Universidade Federal do Paraná, 87 p. Dissertação de Mestrado em Processos Biotecnológicos.

SLATER, J.G., STONE, H.A., PALERMO, B.T. and DUVALL, R.N., 1979. Reliability of Arrhenius Equation in predicting vitamin A stability in multivitamin tablets. Journal of Pharmaceutical Sciences, vol. 68, no. 1, pp. 49-52. http://dx.doi.org/10.1002/ jps.2600680117. PMid:758465.

SONANI, R.R., RASTOGI, R.P. and MADAMWAR, D., 2015. Antioxidant potential of phycobiliproteins: role in anti-aging research. Biochemistry and Analytical Biochemistry, vol. 4, no. 4, pp. 1-8. http://dx.doi.org/10.4172/2161-1009.1000172.
SOUZA, F.T., MARGARITES, A.C., COLLA, L.M., COSTA, J A.V. and BERTOLIN, T.E., 2006. Avaliação do potencial antioxidante da ficocianina em sistema lipídico óleo de soja e azeite de oliva. Alimentos e Nutrição, vol. 17, no. 3, pp. 287-291.

SOUZA, M.M., PRIETTO, L., RIBEIRO, A.C., SOUZA, T.D. and BADIALE-FURLONG, E., 2011. Assessment of the antifungal activity of Spirulina platensis phenolic extract against Aspergillus flavus. Ciência e Agrotecnologia, vol. 35, no. 6, pp. 1050-1058.

TIBURCIO, P.C., GALVEZ, F.C.F., CRUZ, L.J. and GAVINO, V.C., 2007. Determination of shelf life of Spirulina platensis (MI2) grown in the Philippines. Journal of Applied Phycology, vol. 19, no. 6, pp. 727-731. http://dx.doi.org/10.1007/s10811-007-9227-y.

TORRES-DURAN, P.V., FERREIRA-HERMOSILLO, A. and JUAREZ-OROPEZA, M.A., 2007. Antihyperlipemic and antihypertensive effects of Spirulina maxima in an open sample of mexican population: a preliminary report. Lipids in Health and Disease, vol. 6, no. 33, pp. 1-8. PMid:18039384.

VON DER WEID, D., DILLON, J.C. and FALQUET, J., 2000. Malnutrition: a silent massacre. Geneve: Antenna Technology.

VONSHAK, A., 1997. Spirulina platensis (Arthrospira): physiology, cell-biology and biotechnology. London: Taylor \& Francis.

ZHOU, Z.P., LIU, L.N., CHEN, X.L., WANG, J.X., CHEN, M., ZHANG, Y.Z. and ZHOU, B.C., 2005. Factors that effect antioxidant activity of C-phycocyanins from Spirulina platensis. Journal of Food Biochemistry, vol. 29, no. 3, pp. 313-322. http:// dx.doi.org/10.1111/j.1745-4514.2005.00035.x. 